\title{
Design of Demodulation Circuit and Arduino Uno Microcontroller Syncronization for Capacitance Sensor
}

\author{
Menasita $^{1}$, Mirnawati $^{2}$, Sulistijono $^{3}$ \\ ${ }^{1}$ Physics Departement, Kalimantan Institute of Technology, Balikpapan City. Email: menasita@itk.ac.id \\ ${ }^{2}$ Physics Departement, Kalimantan Institute of Technology, Balikpapan City. Email: 01141008@itk.ac.id \\ ${ }^{3}$ Material and Metalurgy Departement, Kalimantan Institute of Technology, Balikpapan City. Email: \\ ssulistijono@mat-eng.its.ac.id
}

\begin{abstract}
An AC signal is produced by oscillator or a similar circuit that includes demodulation. In addition to the demodulation circuit, there is also need interface circuit which include signal conditioning, signal processing and data acquisition. So that, the frequency can be read digitally. The purpose of this research was to create demodulation circuit in form of colpitts-crystal oscillator and microcontroller. This research carried out several stage. There are making colpitts-crystal oscillator, microcontroller synchronization, data retrieval and processing output. The DC voltage variations are $3.2 \mathrm{~V}, 9 \mathrm{~V}$ and $15.9 \mathrm{~V}$ and capacitor variations are $470 \mathrm{pF}, 4.7 \mathrm{nF}$ and 33 $\mathrm{nF}$. Output data in form of frequencies measured by using oscilloscope. Futhermore, the data is tested for accuracy and precision. From the test result using $470 \mathrm{pF}, 4.7 \mathrm{nF}$ and $33 \mathrm{nF}$ capacitors when given $3.2 \mathrm{~V}$ input voltage, the precision values were $91.35 \%, 93.06 \%$ and $96.17 \%$ and the accuracy value were $97.72 \%, 97.96 \%$, and $98.17 \%$. For $9 \mathrm{~V}$ input voltage, the precision values were $99.82 \%, 97.67 \%$ and $97.52 \%$ and the accuracy value were $99 \%$, $98.90 \%$, and $98.92 \%$. Whereas $15.9 \mathrm{~V}$ input voltage, the precision values were $93.43 \%, 96.92 \%$ and $93.66 \%$ and the accuracy value were $98.08 \%, 98.75 \%$, and $97.60 \%$. From these data, it can be concluded that a good voltage value used in this ciecuit is $9 \mathrm{~V}$ with $470 \mathrm{pF}$ capacitor where the precision value was $99.82 \%$ and the accuracy value was $99 \%$.
\end{abstract}

Keywords: Demodulation Circuit, Frequency of Colpitts-Crystal Oscillator, Interface Circuit,

\begin{abstract}
Abstrak
Sinyal AC dihasilkan oleh osilator atau rangkaian serupa yang mencakup demodulasi. Selain rangkaian demodulasi, juga perlu adanya interface circuit yang meliputi signal conditioning, signal processing dan sistem akuisisi data. Sehingga pembacaan keluaran nilai frekuensi dapat dilakukan secara digital pada monitor laptop. Tujuan dalam penelitian ini adalah membuat rangkain demodulasi berupa osilator Colpitts-Kristal dan menyikronkan mikrokontroler untuk digunakan pada sensor. Penelitian ini dilaksanakan beberapa tahap, yakni tahap pembuatan osilator Colpitts-Kristal, tahap sinkronisasi mikrokontroler, kemudian tahap pengambilan data dan pengolahan data hasil keluaran sinyal frekuensi. Variasi yang digunakan pada penelitian ini adalah tegangan masukan DC 3,2 V, $9 \mathrm{~V}$ dan 15,9V serta nilai kapasitor 470pF, 4,7nF dan 33nF. Setelah didapatkan data dari hasil pengukuran frekuensi menggunakan osiloskop dan hasil pengukuran frekuensi dengan sinkronisasi mikrokontroler, selanjutnya data tersebut diuji ketelitian dan keakuratannya. Dalam pengujian alat instrumentasi dilakukan perhitungan ketelitian dan keakuratan. Dari hasil pengujian dengan menggunakan kapasitor 470pF, 4,7nF dan 33nF saat diberi tegangan masukan 3,2 V, nilai ketelitian berturut-turut adalah 91,35\%, 93,06\%, 96,17\% dan nilai keakuratan berturut-turut adalah 97,72\%, 97,96\% dan 98,17\%. Untuk tegangan masukan 9V, nilai ketelitian berturut-turut adalah 99,82\%, 97,67\%, 97,52\% dan nilai keakuratan berturut-turut adalah 99\%, 98,90\% dan 98,92\%. Sedangkan pada tegangan masukan 15,9V, nilai ketelitian berturut-turut adalah 93,43\%, 96,92\%, 93,66\% dan nilai keakuratan berturut-turut adalah 98,08\%, 98,75\% dan 97,60\%. Dari data tersebut dapat disimpulkan bahwa nilai tegangan yang baik digunakan pada alat instrumen ini adalah $9 V$ dengan kapasitor 470pF. Dimana nilai ketelitiannya 99,82\% dan nilai keakuratannya 99\%.
\end{abstract}

Kata Kunci: Rangkaian Demodulasi, Frekuensi Osilator Colpitts-Kristal, Interface Circuit 


\section{Introduction}

In most cases, the percentage change of the output score of inductance, capacitance, resistance (LCR) is very high. Commonly, the big change of the score can be measured using accurate LCR meter. However, in the case of the small percentage change of LCR score such as $100 \mathrm{ppm}$ or even lower then it will be difficult to use common LCR meter. The type of LCR meter with resolution and high secitivity only may be used in laboratory test while in the industry using very sensitive interface circuit (Goes dan Meijer, 1996). In addition for what have been proposed by van der Goes and Meijer is that the measurement of such magnitude of physics which then changed into DC voltage can be used by using demodulation circuit. The demodulation circuit for instance is signal booster and oscillator which change the measurement into DC voltage (Aslam and Boon Tang, 2014).

Oscillator is the circuit that produces the periodic wave in its input by giving DC voltage as the input. The repetitive input voltage is not required except to synchronize the oscillation in several applications. The output signal can be sinusoidal or non-sinusoidal. Such oscillator changes the electrical energy from power supply of DC into the periodic wave form (Floyd, 2012). The output signal often used in the application is sinusoidal signal because it has many types of oscillator that can be used as you wish. From those types of oscillator each of them has its own strengths and weaknesses.

Based on the previous paragraph, it is necessary to make demodulation circuit that can change magnitude of physic into frequency score. Beside the demodulation circuit, it is necessary to have interface circuit including signal conditioning, signal processing and data acquisition system. Simply, this interface circuit is used to connect the hardware on the demodulation circuit and the software in the laptop. Therefore, the output reading of frequency score can be conducted digitally.

\section{Methods}

\subsection{The Circuit-Making Stage of Colpitts-Crystal Oscillator}

Colpitts oscillator is a feedback oscillator circuit which consists of an LC lowpass circuit. The requirement for oscillation is $0^{\circ}$ phase shift through of feedbacks. On the collpits-crystal, the crystal behaves as a series of resonance series if placed as feedback. The crystal seems to have inductance (L), capacitance (C), and resistance (R). (Poole, 2016). Crystal oscillator is used to produce frequencies with a high level of stability. Crystal on the oscillator are made of 
quartz. This material has the ability to convert electrical energy into mechanical energy in the form of vibration or vice versa (Barmawi, 1985)

. Making a colpitts oscillator circuit by adding $12 \mathrm{MHz}$ crystal aims to make the sinusoidal output signal more stable. The oscillator used feedback LC oscillator which is a sinusoidal output signal. The components used in the circuit are batteries, resistors, capacitors, crystals and potentiometers. Oscillator circuit is simulated in the application Multisim National Instrument 13.0 in accordance with the Figure 2.1. Various input voltage of DC in the form of battery is given those are $3.2 \mathrm{~V}, 9 \mathrm{~V}$ and $15.9 \mathrm{~V}$. In the oscilator the score of $C 2$ and $C 3$ are varied with the capacitor score of $470 \mathrm{pF}, 4.7 \mathrm{nF}$ and $33 \mathrm{nF}$ in order can be detected the difference of the frequency score output. The Output of oscillator colpitts-crystal is connected with pin 5 on microcontroller arduino uno. Arduino uno is microcontroller board based on Atmega328. This board has 14 digital pins inputs or outputs where 6 pins can be used as PWM outputs, 6 pins can be used analog input, other pins are for $16 \mathrm{MHz}$ crystal oscillator, USB connection and reset button (Durfee, 2011)

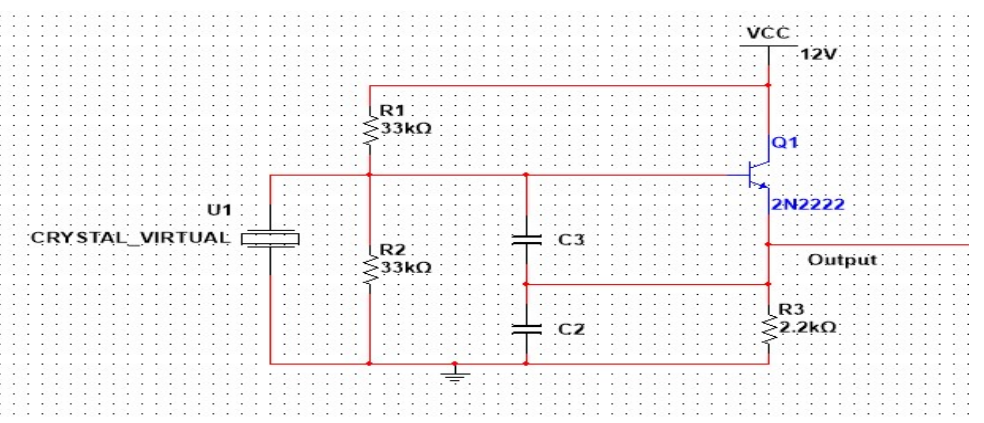

Figure 2.1 Circuit diagram of colpitts-crystal oscillator circuit using NI Multisim 13.0 application Source: Kikkert, C.J., 2009

\subsection{Data collection and Data Processing Stage}

The next stepof this research is data collection and processing of frequency output score displayed on laptop monitor. The output data result is collected on each variant used then process them based on the variant. The data processing is conducted by testing the data in the form of precision and accuracy of such instrumentation circuit. Therefore from this processing data the effective instrumentation circuit can be detected. The precision of such instrumentation system can be calculated using the following equation where $f$ is frequency:

$$
\operatorname{Absolute} \text { Error }(\Delta)=\left[\frac{\sum f-\bar{f}}{n(n-1)}\right]^{\frac{1}{2}}
$$




$$
\begin{gathered}
\text { Eror (I) } \quad=\frac{\Delta}{\bar{f}} \times 100 \% \\
\text { Precision } \quad=100 \%-\mathrm{I} \\
\text { \% Error Accuracy }=1-\left|\frac{\text { Score expected - Nilai measured }}{\text { Score expected }}\right| \\
\% \text { Accuracy } \quad=100 \%-\text { Error Accuracy }
\end{gathered}
$$

\section{Result and Discussion}

\subsection{Data Analysis and Discussion}

Precision and accuracy of data obtained from testing instrumentation. Precision is the score of the accuracy of data while accuracy is the proximity of the sensor output to the actual value. The actual value of this research is the frequency of the osciloscope. The precision and accurancy equation can be seen in sub-chapter 2.2. The precision and the accuracy value of each variable can be seen in the tables 3.1. and 3.2.

Tabel 3.1 The Calculation Result of Precision

\begin{tabular}{ccccc}
\hline $\begin{array}{c}\text { Voltage Input } \\
\text { in DC (V) }\end{array}$ & Capacito & Absolute Error & Error (\%) & Precision (\%) \\
\hline \multirow{2}{*}{3,2} & $470 \mathrm{pF}$ & 9.84 & 8.65 & 91.35 \\
& $4,7 \mathrm{nF}$ & 7.07 & 6.94 & 93.06 \\
& $33 \mathrm{nF}$ & 3.50 & 3.83 & 96.17 \\
\hline \multirow{2}{*}{9} & $470 \mathrm{pF}$ & 0.09 & 0.18 & 99.82 \\
& $4,7 \mathrm{nF}$ & 1.26 & 2.33 & 97.67 \\
& $33 \mathrm{nF}$ & 1.35 & 2.48 & 97.52 \\
\hline \multirow{2}{*}{15,9} & $470 \mathrm{pF}$ & 6.30 & 6.57 & 93.43 \\
& $4,7 \mathrm{nF}$ & 1.94 & 3.08 & 96.92 \\
& $33 \mathrm{nF}$ & 7.72 & 6.34 & 93.66 \\
\hline
\end{tabular}

Tabel 3.2 The Calculation Result of Accuracy 


\begin{tabular}{cccccc}
\hline $\begin{array}{c}\text { Input Voltage } \\
\text { in DC (V) }\end{array}$ & Capacitor & $\begin{array}{c}\text { Score } \\
\text { expected (in } \\
\text { oscilloscope }\end{array}$ & $\begin{array}{c}\text { Score } \\
\text { Measured }\end{array}$ & $\begin{array}{c}\text { Error } \\
\text { Accuracy } \\
\mathbf{( \% )}\end{array}$ & Accuracy (\%) \\
\hline \multirow{2}{*}{3,2} & $470 \mathrm{pF}$ & 50.05 & 114 & 2.28 & 97.72 \\
& $4,7 \mathrm{nF}$ & 49.82 & 101.76 & 2.04 & 97.96 \\
\hline \multirow{2}{*}{9} & $33 \mathrm{nF}$ & 49.98 & 91.45 & 1.83 & 98.17 \\
& $470 \mathrm{pF}$ & 50.16 & 50 & 1.00 & 99.00 \\
& $4,7 \mathrm{nF}$ & 49.37 & 54.22 & 1.10 & 98.90 \\
\hline \multirow{2}{*}{15,9} & $33 \mathrm{nF}$ & 50.63 & 54.54 & 1.08 & 98.92 \\
\hline & $470 \mathrm{pF}$ & 49.98 & 96 & 1.92 & 98.08 \\
& $4,7 \mathrm{nF}$ & 50.11 & 62.86 & 1.25 & 98.75 \\
& $33 \mathrm{nF}$ & 50.85 & 121.84 & 2.40 & 97.60 \\
\hline
\end{tabular}

Discussion

The data obtained from frequency value are processed into a graph of the frequency relationship with time. Figure 3.1 is graph when the DC input is $3.2 \mathrm{~V}$. The $\mathrm{x}$-axis in the graph is time (s) and $y$-axis is frequency $(\mathrm{Hz})$. Through this graph, the distribution of data for each capacitor variation is displayed. $470 \mathrm{pF}$ capacitors have poor data distribution which is having many peaks with different heights. Data distribution can also be seen from the precision of the test data in table 3.1. The precision value for $470 \mathrm{pF}$ capasitor is the lowest of all values, namely $91.35 \%$ with higher error $8.65 \%$. Meanwhile, figure 3.1 shows good data distribution when using $33 \mathrm{nF}$ capasitor where the error is below $5 \%$, which is $3.83 \%$.

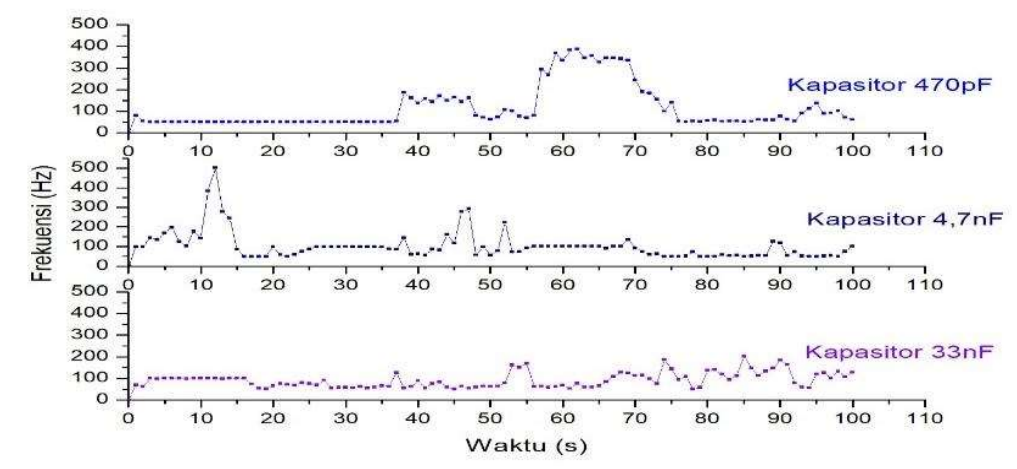

Figure 3.1 Graph of frequency score with input voltage DC 3.2V 
After that, the graph for voltage variant $9 \mathrm{~V}$ is shown by the Figure 3.2. This graph depicts the data distribution on each variant of capacitor score. Capacitor with $470 \mathrm{pF}$ has good data distribution. It also can be seen from the testing precision score on table 3.1. The precision score for capacitor $470 \mathrm{pF}$ is the highest from all variants that is $99.82 \%$ with lowest error score $0.18 \%$. The last graph is the relationship graph of frequency against time on input voltage

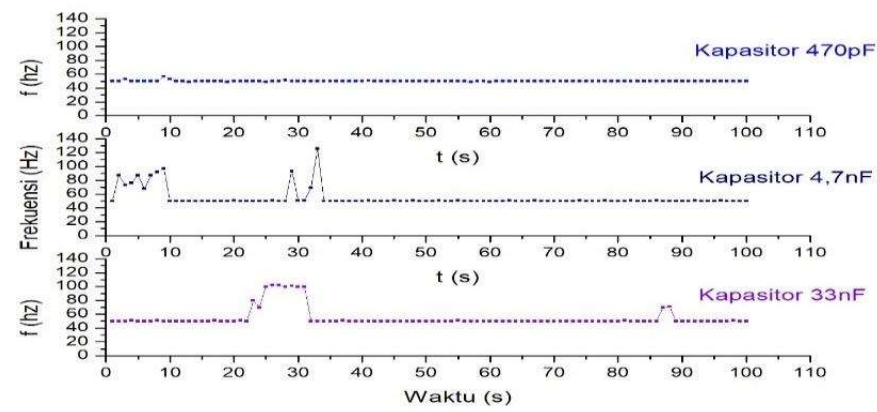

Figure 3.2 Graph of frequency score with input voltage DC 9V

variant $15.9 \mathrm{~V}$. Capacitor with score $470 \mathrm{pF}$ and $33 \mathrm{nF}$ has less good data distribution. Many culminations with different height produced. This data distribution also can be seen from the precision score of data testing on table 3.1. The precision score of capacitor $470 \mathrm{pF}$ is the lowest from all variant that is $93.43 \%$ with the highest error score $6.57 \%$. In the capacitor $33 \mathrm{nF}$ the precision score is $93.66 \%$. In the other hand, the figure of graph 3.3 the data distribution is good in which it is used capacitor $4.7 \mathrm{nF}$ with error score under $5 \%$ that is $3.08 \%$ and the precision score is $96.92 \%$.

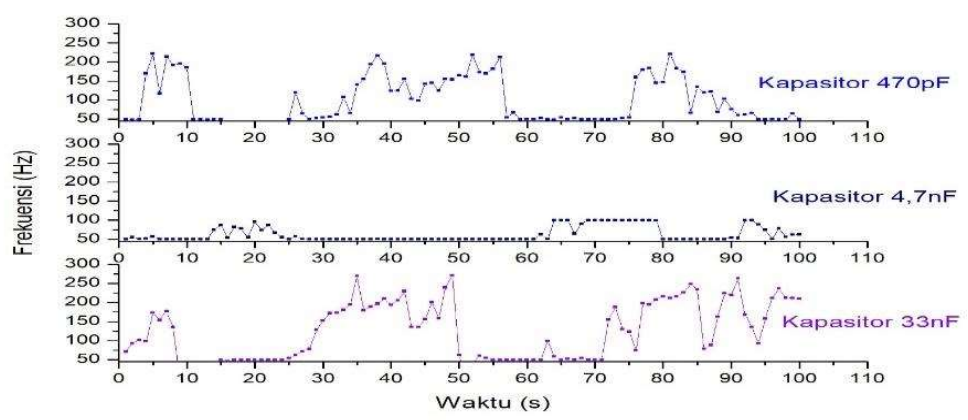

Figure 3.3 Graph of frequency score with input voltage DC $15.9 \mathrm{~V}$

According to the result of precision testing, it is known that when using input voltage $3.2 \mathrm{~V}$ the lowest result is when using capacitor $470 \mathrm{pF}$ with error score $8.65 \%$ and the precision score is $91.35 \%$.therefore, if want to use input voltage with range score of $3.2 \mathrm{~V}$ it is better to not use capacitor $470 \mathrm{pF}$ but using capacitor $33 \mathrm{nF}$ because it has error score only $3.5 \%$ and the precision score is $96.17 \%$. When the input voltage is $9 \mathrm{~V}$, the highest precision score is $99.82 \%$ when use capacitor $470 \mathrm{pF}$. While in input voltage $15.9 \mathrm{~V}$, the highest precision score is $96.92 \%$ 
when use capacitor $4,7 \mathrm{nF}$. The error score above $5 \%$ from table 3.1 is for the precision testing occur when the input voltage $3.2 \mathrm{~V}$ and $15.9 \mathrm{~V}$. therefore the precision score also can be obtained by using input voltage score $9 \mathrm{~V}$, the precision score from the result of instrumentation tool testing is in highest range $99.82 \%$ up to $97.52 \%$ with lowest error level that is in range $0.18 \%$ up to $2.48 \%$. The occurrence of instability data distribution when using input voltage $3.2 \mathrm{~V}$ and $15.9 \mathrm{~V}$ is caused by the noise produced by the environment during the process of instrumentation tool testing. Meanwhile, the stability of data distribution obtained using input $9 \mathrm{~V}$ is due to the less noise produced in environment that influences the data. The noise occurs due to the environment condition and different time of data collection. In addition, input voltage 9V use one battery DC as the source, contrarily in input voltage $3.2 \mathrm{~V}$ and $15.9 \mathrm{~V}$ which is the result of voltage battery series of DC $1.5 \mathrm{~V}$ and $9 \mathrm{~V}$. From this series circuit on voltage battery of DC $1.5 \mathrm{~V}$ and $9 \mathrm{~V}$ produce disturbing noise toward the stability of data distribution when using input voltage $3.2 \mathrm{~V}$ and $15.9 \mathrm{~V}$.

In the table 3.2, the accuracy table is in the range $97.6 \%$ up to $99 \%$. According to the result of the accuracy testing, when the input voltage is $3.2 \mathrm{~V}$ the highest accuracy score is $98.17 \%$ with error accuracy $1.83 \%$ when using capacitor $33 \mathrm{nF}$. In addition, using the same input voltage score, the lowest accuracy score is when using capacitor $470 \mathrm{pF}$ that is $97.72 \%$. When the voltage is raised become $9 \mathrm{~V}$ and $15.9 \mathrm{~V}$, the accuracy score is changed on each variable. The highest accuracy score is when using capacitor $470 \mathrm{pF}$ that is $99 \%$. On the contrary, when the input voltage is $15.9 \mathrm{~V}$, the highest accuracy is using capacitor $4,7 \mathrm{nF}$. None error accuracy score over 3\% from all variables of data tested, but the highest error accuracy score is occurred when using input voltage $3.2 \mathrm{~V}$ that is $2.28 \%$ and the input voltage of $15.9 \mathrm{~V}$ that is $2.40 \%$. Therefore, according to the accuracy testing of this instrumentation tool, input voltage $9 \mathrm{~V}$ which has highest accuracy score is in the range score of $99 \%$ up to $98,92 \%$. Form both testing, the input voltage score $9 \mathrm{~V}$ is the input voltage recommended by the writer due to the highest range of precision and accuracy.

\section{Conclusion}

The conclusion obtained from the current research is that using score of input voltage $9 \mathrm{~V}$, the precision score of testing result of instrumentation tool testing is in highest range $9.82 \%$ with capacitor score $470 \mathrm{pF}$ and low error level that is $0.18 \%$. The accuracy testing of instrumentation tool with input voltage $9 \mathrm{~V}$ also have highest accuracy score $99 \%$ with capacitor score $470 \mathrm{pF}$. Therefore according to both tests, the input voltage $9 \mathrm{~V}$ is the input voltage with highest precision and accuracy range. 


\section{References}

Alter, David, M. (2008), "Using PWM Output as a Digital-to-Analog Converter on a TMS320F280x TM Digital Signal Controller", Texas Instrument, SPRAA88A.

Aslam, Muhammad Zubair, Boon Tang, Tong. (2014). A High Resolution Capacitive Sensing System for The Measurement of Water Content in Crude Oil. PubMed. Sensors 2014, 14. Barmawi, Malvino. (1985). Prinsip-prinsip Elektronika. Erlangga. Jakarta.

Davoudi, Ali, Jetskervich, J. (2006), "Realization of Parasitics in State-Space Average-Value Modeling of PWM DC-DC Converers", IEEE Transactions on Power Electronic, Vol.21, No.4.

Durfee, W. (2011). Arduino Microcontroller Guide, University of Minnedota.

Goes, Van der F. M. L, and Meijer, G. C. M. (1996). A Nvel Low-Cost Capacitive-Sensor Interface, IEEE Trans on Instrum. Meas, vol. 45, No. 2. Pp. 536-540, April.

Kikkert, C.J. (2009), RF Electronics, Chapter 6: Oscillators, AWR Corp.

Floyd, Thomas L. (2002), ElectronicDevices Conventional Current Version, $9^{\text {th }}$ Edition, Prentice Hall, New Jersey.

Floyd, Thomas L., Buchla, D. (2005), Fundamental of Analog Circuits, $2^{\text {nd }}$ Edition, Prentice Hall, New Jersey.

Poole, Clive, Darwazeh, I (2016). Microwave Active Circuit analysis and Design, Elsevier Ltd., University Collage London. 